\title{
CENTRALIZÁCIÓ ÉS GAZDASÁGI CIKLUSOK: MIÉRT KÖZPONTOSÍTUNK AKKOR IS, HA MÁR NEM KÉNE?
}

\author{
- EGY KVALITATÍV MEGKÖZELÍTÉS
}

Válság idején a vállalatok centralizálnak, hogy növeljék hatékonyságukat. Azonban a hatalomkoncentráció rövid távú elónyei felülírják annak hátrányait. Másrészrốl, mivel a vállalatok hajlamosabbak fellendülés idején decentralizálni, ezért láthatjuk, hogy a szervezetek a gazdasági ciklusoknak megfelelóen változtatják centralizációjuk szintjét. Magyar és brit felsố vezetôkkel készített interjúk alapján e tanulmány egy olyan elméleti modellt vázol fel, mely megmutatja, hogy egyes vállalatok miért hajlamosak az ideálisnál tovább fenntartani a központosítást. A megfeleló időben történő átalakítással a szervezetek adaptációs előnyre tehetnek szert.

\section{Kulcsszavak: centralizáció, decentralizáció, versenyképesség, döntéshozatal}

A döntéshozatali jogok átstrukturálása egy eszköz lehet a környezethez való alkalmazkodásban. Mivel az adaptáció előnyt jelent, a megfelelő időben történő centralizáció növelheti a vállalat versenyképességét.

E kvalitatív tanulmány a gazdasági válság és a centralizáció (azaz a döntéshozatali jogokban történő koncentrációnövekedés) közötti kapcsolatot vizsgálja. A 2007-2008-ban a Nagy Világválságot követő legnagyobb recesszióval kellett szembenéznie a világgazdaságnak (Reinhart-Rogoff, 2009). Mivel a válság mindig egy érdekes világállapot a vállalatok döntéshozatalának vizsgálatához (Higgins - Freedman, 2013) a jelzáloghitel válság egy szerencsétlen, mégis hasznos alkalom a centralizáció vizsgálata szempontjából.

Természetesen minden vállalatnak reagálnia kellett a válságra valamiféleképpen, rengeteg válságstratégia jelent meg, köztük a vállalati döntéshozatali jogkörök átalakítása (centralizáció vagy decentralizáció) is. Számos korábbi tanulmány vizsgálta már a környezeti változást és a centralizációt mind empirikus (Richardson et al., 2002; Kunisch et al., 2012; Aghion - Bloom, 2014), mind matematikai modellek segítségével (Aghion - Tirole, 1997; Marin - Verdier, 2008; Davis et al., 2009).

Ezen interjúalapú kvalitatív tanulmány elsődleges célja, hogy új módszertani megközelítéssel hozzájá- ruljon a terület egyik legérdekesebb vitájához. E vita egyik oldala azt állítja, hogy válság idején a vállalatok centralizálnak (Pfeffer - Leblebici, 1973; Richardson et al., 2002; Davis et al., 2009; Kunisch et al., 2012), míg a másik a decentralizáció mellett érvel (Aghion - Tirole, 1997; Marin - Verdier, 2008; Alonso et al., 2008; Aghion - Bloom, 2014). A terület egyik legfókuszáltabb (paneladatokra épüló) tanulmánya kijelenti, hogy azoknak a vállalatoknak, melyek válság idején decentralizáltak, növekedett a termelékenységük és az árbevételük (Aghion - Bloom, 2014).

E tanulmány egy centralizációval foglalkozó kutatássorozat második hulláma. Az elsô egy keresztmetszeti ökonometriai elemzés volt, mely a 14.000 európai ipari vállalat adataira építő EFIGE-adatbázison belátta, hogy a válság növeli a vállalati centralizáció esélyét (Bakonyi, 2015). E második, kvalitatív tanulmány 13 felsővezetói interjúra épít, akiket arról kérdeztem, hogy miért centralizáltak vagy decentralizáltak a válság alatt. E kutatás célja, hogy hozzájáruljon a kvantitatív kutatások által dominált szakterülethez, deskriptív megközelítéssel bemutatva, hogy milyen okok állnak a döntéshozatal koncentrációja mögött.

A centralizáció mélységi megértése alapjaiban befolyásolhatja a vállalati teljesítményt, mivel a centralizált 
vállalatok elsősorban hatékonyságban erôsebbek, míg a decentralizáció növeli az innovációs készséget (Davis et al., 2009). Így a centralizált vállalatok innovációs hajlama időben csökkenhet. Emiatt a tanulmány legfontosabb kérdése az, hogy ha olyannyira hasznos a decentralizáció, mégis a vállalatok miért centralizálnak válság idején?

A cikk első része részletesen bemutatja az alkalmazott módszertant. A következő fejezet mélységében elemzi a válság alatti centralizáció és decentralizáció legfontosabb okait. Több interjúalany is megemlítette, hogy egyes vállalatok hosszú távon is fenntartották a megnövekedett centralizációt. Azonban, mint azt már korábban láthattuk, a centralizáció jelentős hátrányokkal is járhat (kevesebb innováció, lassabb növekedés). Emiatt kulcsfontosságú, hogy megértsük, hogy miért tartják fent egyes vállalatok a centralizációt hosszú távon is. Az utolsó fejezet egy olyan elméleti modellt mutat be, mely leírja, hogy a vállalatok döntéshozatali struktúrája miként alkalmazkodik a gazdasági ciklusokhoz.

\section{A módszertan}

A kutatási kérdés elemzéséhez egy félig-strukturált interjúkon alapuló, kvalitatív módszertant alkalmaztam három okból. Először is, e módszertan segít, hogy komplex társadalmi rendszereket mélységében elemezzünk (Selmier et al., 2015). Másodszor, e megközelítés új példákkal és megfigyelésekkel egészítheti ki a meglévó elméleteket (Eisenhardt - Graebner, 2007). Harmadszor, ezáltal mélységében is megérthetjük a centralizációról döntô felső vezetők személyes interpretációit is. Ellentétben számos, különböző definíciókat alkalmazó empirikus és matematikai modellekkel, jelen kutatás az egyén szemszögéból mutatja be a valódi döntéshozók érveit és véleményeit.

Szemben a kvantitatív (kérdőívalapú) módszertanokkal ezen interjúalapú kutatás mélységében képes elemezni a fenti kutatási kérdést. Például a felsô vezetôknek lehetőségük van a centralizáció mellett, illetve ellen annyi érvet felsorolni, amennyit csak fontosnak tartanak, valamint később ezeket súlyozhatják, priorizálhatják. Sốt e módszertannal még azokat az érveket

1. táblázat

A kutatásban részt vevố vállalatok

\begin{tabular}{|c|c|c|c|c|c|c|c|c|c|}
\hline $\begin{array}{c}\text { Vállalat } \\
\text { kódja }\end{array}$ & $\begin{array}{c}\text { Interjúalany } \\
\text { beosztása }\end{array}$ & Dátum & Ország & $\begin{array}{l}\text { Vállalat- } \\
\text { méret }\end{array}$ & Iparág & $\begin{array}{c}\text { Csoport- } \\
\text { tagság }\end{array}$ & $\begin{array}{c}\text { Forgalom- } \\
\text { változás }\end{array}$ & $\begin{array}{c}\text { Eredeti } \\
\text { centralizáció }\end{array}$ & $\begin{array}{c}\text { Centralizáció } \\
\text { változása } \\
\end{array}$ \\
\hline HUN Pharma & $\begin{array}{l}\text { pénzügyi } \\
\text { igazgató }\end{array}$ & 2013.01.18 & HUN & nagy & gyógyszergyártás & független & $\begin{array}{c}10 \% \\
\text { növekedés }\end{array}$ & NA & centralizáció \\
\hline HUN Engin & $\begin{array}{c}\text { ügyvezetó } \\
\text { igazgató }\end{array}$ & 2014.08.05 & HUN & közép & $\begin{array}{c}\text { termelési } \\
\text { rendszerek }\end{array}$ & $\begin{array}{c}\text { nemzetközi } \\
\text { csoporttag }\end{array}$ & $\begin{array}{c}10-30 \% \\
\text { csökkenés }\end{array}$ & centralizált & centralizáció \\
\hline HUN Cosmet & $\begin{array}{l}\text { üzletfejlesz- } \\
\text { tési igazgató }\end{array}$ & 2014.08 .05 & HUN & kis & $\begin{array}{c}\text { kézmúves } \\
\text { kozmetikumok }\end{array}$ & független & $\begin{array}{c}30 \%+ \\
\text { csökkenés }\end{array}$ & decentralizált & decentralizáció \\
\hline HUN Proth & $\begin{array}{c}\text { ügyvezető } \\
\text { igazgató }\end{array}$ & 2014.08 .14 & HUN & kis & múvégtaggyártás & $\begin{array}{c}\text { hazai cso- } \\
\text { porttag }\end{array}$ & $\begin{array}{c}10-30 \% \\
\text { csökkenés }\end{array}$ & decentralizált & decentralizáció \\
\hline $\begin{array}{c}\text { HUN } \\
\text { Material }\end{array}$ & $\begin{array}{c}\text { ügyvezetó } \\
\text { igazgató }\end{array}$ & 2014.08 .15 & HUN & nagy & $\begin{array}{c}\text { építóipari } \\
\text { alapanyagok }\end{array}$ & $\begin{array}{c}\text { nemzetközi } \\
\text { csoporttag }\end{array}$ & $\begin{array}{c}10-30 \% \\
\text { csökkenés }\end{array}$ & centralizált & centralizáció \\
\hline HUN Metal & $\begin{array}{c}\text { vezérigaz- } \\
\text { gató }\end{array}$ & 2014.09.10 & HUN & közép & $\begin{array}{c}\text { fémhulladék } \\
\text { feldolgozás }\end{array}$ & független & $\begin{array}{c}10-30 \% \\
\text { csökkenés }\end{array}$ & decentralizált & decentralizáció \\
\hline HUN Wheel & $\begin{array}{l}\text { vezérigaz- } \\
\text { gató }\end{array}$ & 2014.10.01 & HUN & nagy & kerékgyártás & független & $\begin{array}{c}30 \%+ \\
\text { csökkenés }\end{array}$ & centralizált & centralizáció \\
\hline UK Light & $\begin{array}{c}\text { vezérigaz- } \\
\text { gató }\end{array}$ & 2015.01.09 & UK & kis & $\begin{array}{c}\text { speciális elektro- } \\
\text { nikus eszközök }\end{array}$ & független & $\begin{array}{c}10-30 \% \\
\text { csökkenés }\end{array}$ & centralizált & centralizáció \\
\hline UK Electro & $\begin{array}{l}\text { üzletfejlesz- } \\
\text { tési igazgató }\end{array}$ & 2015.01.14 & UK & nagy & $\begin{array}{c}\text { elektronikus } \\
\text { eszközgyártás }\end{array}$ & független & $\begin{array}{c}10-30 \% \\
\text { csökkenés } \\
\end{array}$ & decentralizált & centralizáció \\
\hline UK Print & $\begin{array}{c}\text { ügyvezető } \\
\text { igazgató }\end{array}$ & 2015.01 .15 & UK & közép & $\begin{array}{c}\text { prémium } \\
\text { nyomdagépek }\end{array}$ & $\begin{array}{c}\text { nemzetközi } \\
\text { csoporttag }\end{array}$ & $\begin{array}{c}30 \%+ \\
\text { csökkenés }\end{array}$ & centralizált & centralizáció \\
\hline UK Cons & $\begin{array}{c}\text { ügyvezető } \\
\text { igazgató }\end{array}$ & 2015.01.21 & UK & nagy & $\begin{array}{c}\text { építészeti } \\
\text { rendszerek }\end{array}$ & $\begin{array}{c}\text { nemzetközi } \\
\text { csoporttag }\end{array}$ & $\begin{array}{c}10-30 \% \\
\text { csökkenés } \\
\end{array}$ & decentralizált & centralizáció \\
\hline UK Material & $\begin{array}{l}\text { ügyvezető } \\
\text { igazgató }\end{array}$ & 2015.02 .03 & UK & közép & $\begin{array}{c}\text { építőipari } \\
\text { alapanyagok }\end{array}$ & $\begin{array}{c}\text { nemzetközi } \\
\text { csoporttag }\end{array}$ & $\begin{array}{c}10-30 \% \\
\text { csökkenés }\end{array}$ & centralizált & centralizáció \\
\hline UK DIY & $\begin{array}{l}\text { pénzügyi } \\
\text { igazgató }\end{array}$ & 2015.02 .24 & UK & közép & $\begin{array}{l}\text { barkácsesz- } \\
\text { köz-gyártás }\end{array}$ & független & $\begin{array}{c}30 \%+ \\
\text { csökkenés }\end{array}$ & centralizált & centralizáció \\
\hline
\end{tabular}


is elemezhetjük, melyeket az interjúalanyok nem említettek meg, és ez hozzájárulhat a meglévő elméletek fejlesztéséhez is.

Jelen tanulmány egy korábbi kvantitatív elemzésre épül, mely az EFIGE-adatbázist vizsgálta. Az adatbázis 14.759 , tíz fơnél nagyobb, európai, ipari vállalat keresztmetszeti adatait tartalmazza 2008-2009-ből. $\mathrm{Az}$ Ausztriában, Franciaországban, Németországban, Magyarországon, Olaszországon, Spanyolországon és az Egyesült Királyságban megkérdezett felső vezetők nagy mennyiségú információt osztottak meg a foglalkoztatás, export, beruházások, verseny, finanszírozás és szervezeti struktúra témaköreiben (Altomonte - Aquilante, 2012, p. 6.). Az első kutatási hullám eredményei bemutatták, hogy a válság növeli a centralizáció esélyét (Bakonyi, 2015). Mivel a vegyes módszertanok jobban segítik a társadalmi jelenségek alaposabb megértését, gazdagabb eredményekhez juthatunk általuk (Mason, 2006).

Az első interjút 2013-ban egy közép-európai gyógyszeripari vállalat felső vezetőjével készítettem. Az elózetes kutatás tapasztalatai nagyban hozzájárultak a végleges kutatási módszertan kifejlesztéséhez. A többi interjúalanyt az EFIGE-adatbázisból választottam a következő protokoll szerint. Olyan magyar (javarészt Budapest-környéki) és brit (javarészt London-környéki) vállalatokat kerestem ki az adatbázisból, melyek megfelelnek az alábbi kritériumoknak. (1) 2009-ben 10\%nál nagyobb forgalom-visszaeséssel szembesültek, (2) centralizálták vagy decentralizálták a stratégiai döntéshozatalukat, (3) még mindig múködtek (2014-ben vagy 2015-ben), és (4) rendelkeztek legalább egy olyan felsố vezetôvel, aki 2009-ben is pozícióban volt.

Internetes keresést alkalmaztam a még múködő 16 magyar és 13 brit vállalat felkutatására. Tíz magyar és hét brit vállalat explicite vagy implicite visszautasította a kutatásban való részvételt. Azonban 6-6 vállalat elfogadta a felkérést, így 2014 nyarán hat magyarországi vállalatvezetôvel készítettem személyes interjút, 2015 telén pedig hat brit felső vezetôt interjúvoltam meg videókonferencián vagy telefonon keresztül (1. táblázat). A minta tíz vállalata centralizált, 3 decentralizált, mely eloszlás megegyezik az egész EFIGE-adatbáziséval.

A minta legfontosabb korlátai a következők. (1) Kizárólag ipari vállalatokat tartalmaz, ami nem reprezentálja a teljes gazdaságot. (2) Csak magyar és brit vállalatokat elemez, azonban a centralizációs magatartás függ a kulturális kontextustól is (Aghion et al., 2013). (3) E vállalatok túlélték a válságot: ốk a „,szerencsés kevesek" közé tartoznak. Talán teljesen másképpen centralizáltak, mint ahogy azt a csődbement vállalatok tették. A befolyásolás minimalizálása érdekében a felső vezetôket csak nagyvonalakban tájékoztattam a kutatásról, illetve az interjú főbb részeiről. Ezzel együtt, hogy könnyebben visszaemlékezhessenek az eseményekre, mindig megemlítettem, hogy milyen választ adtak az EFIGE-adatbázisban a centralizáció változásáról szóló kérdésre. Az összes interjút szóról-szóra begépeltem, majd visszaküldtem az interjúalanyoknak a módosítás lehetôségével. Kizárólag a végleges, láttamozott, vagy módosított interjúszöveget alkalmaztam az elemzésnél. A titoktartási megállapodás miatt az interjúalanyok és munkáltatóik neve rejtve marad az elemzésben, ahogyan az egész kutatás során is titkosítva voltak.

Szintén a befolyásolás minimalizálása miatt az interjúalanyokat nem tájékoztattam a centralizációs irodalom legfontosabb eredményeiről, ahogyan a kutatás előző, válság és centralizáció kapcsolatát vizsgáló hullámáról sem. Egy félig-strukturált, narratív-jellegú interjúrendszert alkalmaztam, mely lehetővé tette, hogy csak az interjú fő témáit határozzam meg (válság, válságreakciók, centralizáció), azok tárgyalásának mélységét az interjúalanyok dönthették el.

$\mathrm{Az}$ interjúk végén még a helyszínen megosztottam az interjúalanyokkal az általam értelmezett fóbb pontokat. A végleges interjú láttamozását követően minden szövegről készítettem egy egyoldalas összefoglalót, melyek hasznosak voltak a későbbi elméletépítéshez. Ezeket követően sokszorosan kódoltam a teljes interjúszövegeket a korábban ismert elméletek és a kialakuló koncepciók alapján. A köztes eredményeket négy szenior kutatótársammal osztottam meg. Visszajelzéseikre és az eredeti eredményekre építve e tanulmányt 2015ben készítettem el.

\section{A válságreakciók}

A jelzálogpiaci válságot követôen a vállalatoknak súlyos válságtényezőkkel kellett szembenézniük. Ezek között találjuk (1) az összeszúküllt keresletet, (2) a csökkent likviditást, valamint (3) a növekvő bizonytalanságot (OECD, 2012). A növekedéshez, illetve a túléléshez a vállalatoknak új stratégiákat kellett kidolgozniuk ebben a radikálisan megváltozott környezetben.

A válságreakciókat tekintve jelentős különbségeket találunk az egyes vállalatok közöttt ${ }^{1}$ (Békés et al., 2011). Wilson és Eilertsen (2010) szerint defenzív és offenzív stratégiák is megjelentek a válság kezelése során.

Offenzív stratégiák:

- új termékek,

- új piacokra való belépés,

- új árazás,

- új termelési berendezésekbe való beruházás, és

- a marketing-költségvetés növelése.

Defenzív stratégiák:

- múködési költségek csökkentése,

- új munkatárs-felvételek megállítása, 
- létszámleépítés,

- a tréning és K+F költségek csökkentése, és

- a nagyobb projektek szüneteltetése (Wilson - Eilertsen, 2010, p. 4.).

A csökkent kereslet és likviditás a vállalatokat hatékonyságnövelésre ösztökélte (OECD, 2012). Másrészről azon vállalatok, melyek radikális átalakítást végeztek, sikeresebbek lettek, mint azok, melyek kizárólag költségcsökkentést vittek véghez (Barker - Duhaime, 1997). Egy McKinsey-tanulmány szerint a jelentôs erőforrás újraallokációt végző vállalatok profitabilitása jelentősen növekedett (Fruk et al., 2013), sőt akik mindezt gyorsabban végezték el, azok még nyereségesebbek lettek (Hall - Kehoe, 2013).

A rövid távú stratégiákat azonban a megnövekedett bizonytalanság motiválta leginkább (Kunc - Bhandari, 2011). Mivel, ahogyan azt Smart és Vertinsky (1984) is kifejti, jelentős, stratégiai változtatást könnyebb stabil környezetben végrehajtani. Sőt a bizonytalanság általában még a beruházási és innovációs kedvet is csökkenti (OECD, 2012).

De miként hoz döntést a menedzsment a stratégiáról válságidôszakban? Ez idő tájt a vállalatvezetőknek három jelentős döntéshozatali kihívással kell szembenézniük: (1) kevesebb idejük jut a döntéshozatalra, (2) kevesebb információval rendelkeznek, és (3) megnövekszik a leterheltségük (Cosgrave, 1996). Hogy jobban megértsük ezt a folyamatot, meg kell vizsgálnunk a vállalat döntéshozatali jogainak struktúráját.

\section{A centralizáció mint válságreakció}

\section{A centralizáció fogalma}

A centralizációra számtalan definíciót találunk az irodalomban. Egyes alkotók a menedzserek által meghozható döntések körére fókuszálnak (Child, 1972; Richardson et al., 2002; Lin -Germain, 2003). Hasonló logikát figyelhetünk meg azon tanulmányokban, melyek azt vizsgálják, hogy a szervezet egyes tagjai milyen gyakran vehetnek részt bizonyos döntések meghozatalában (Hage - Dewar, 1973). A centralizált szervezetrôl beszélünk abban az esetben, ha egy magasabb hierarchiaszintnek láttamoznia kell egy döntést (Gates - Egelhoff, 1986) vagy más módon kontrollt gyakorol a folyamat felett (Pfeffer - Leblebici, 1973).

A centralizáció szemszögéből több tanulmány foglalkozott már a multinacionális vállalatok általános szervezeti struktúrájával (Keats - Hitt, 1988; Nohria - Goshal, 1994), vagy a vállalati központ és a szervezeti egységek viszonyával is (Golden 1992; Argyres - Silverman, 2004). És mivel a formális és informális autoritás eltérhet a szervezetekben (Cohen - Lachman, 1988), többen kutatták már az alternatív döntéshozata- li struktúrákat is a vállalatok belül (Nohria - Goshal, 1994; Adams et al., 2005).

Bár lehet, e tanulmány alanyai az EFIGE-adatbázisban azt említették, hogy a stratégiai döntéshozatalukat központosították, az interjúk során világossá vált, hogy a centralizációt sokkal tágabban ragadják meg. A stratégiai menedzsment mindhárom fázisából említettek példát a központosításra, mind (1) a stratégiaalkotás; (2) a végrehajtás és (3) a kontroll szemszögéből.

\section{A stratégiaalkotás}

A stratégiaalkotás központosítása azt jelenti, hogy egyre kevesebb embert vonnak be a szervezetet érintó kulcskérdések meghozatalába. Ennek két fajtáját különböztethetjük meg az interjúk alapján. Az első a de jure centralizáció, mely a vállalatirányítás átalakítását jelenti. „Lehetôségünk volt, hogy zártkörú részvénytársaságként megszüntessük az igazgatóságot és akkor éltünk is ezzel (...), hogy csökkentsük a költségeket" (HUN WHEEL). A második pedig a de facto centralizáció, mely a központosítás egyik legnépszerúbb fajtája volt. A de facto központosítás akkor történik, amikor a felettes egyszerúen kevesebb döntésbe vonja be a beosztottját, mint korábban. „Minden döntést a (vezérigazgatói) szobában hoztunk meg. Nyilvánvaló volt, hogy nem lehetett az egyes üzletágaknak üzletágszintú, a cég akkori stratégiájától független döntéseket meghozniuk" (HUN Engin).

E két központosítási forma nagyon hasonló Aghion és Tirole (1997) formális és valódi autoritás koncepciójához. Habár több alkotó is megkülönbözteti a stratégiai és funkcionális döntések centralizációját (pl. Baum - Wally, 2013; Kunisch et al., 2012) ez a különbségtétel kiváltképp nehéz, amikor egy vállalat extrém módon központosított. „A vevőkapcsolatok nagyon fontosak, így nem arról volt szó, hogy azokat megszüntessük, de más csatornákon keresztül értük el ügyfeleinket. Voltak olyan kiadványaink (pl. a vállalati magazin), amelyeket abban az évben nem nyomtatott, hanem (vezérigazgatói döntés alapján) elektronikus formában adtunk ki” (HUN Engin).

\section{A végrehajtás}

A végrehajtás centralizációja azt fejezi ki, hogy a stratégia implementációját mennyi ember menedzseli. Egyes kutatók kifejezetten a funkcionális implementációra fókuszálnak a központosítás kutatásánál (pl. Ling et al., 2008). Erre példa lehet egy decentralizáló interjúalany esete „szélesebb palettán dolgozunk, emiatt több középvezetôt alkalmazunk, de (továbbra is a) stratégiai döntéseket az igazgatóság hozza. Annak előkészítését, végrehajtását a menedzsment végzi” (HUN Proth).

Mi több, a szervezeti átalakítások is okozhatják az autoritás központosítását. „(A válság előtt) nagyjából 
eléggé decentralizált volt a (...) beszerzés és ekkor egy vállalatátszervezési projekt keretében néhány kivételével az összes szolgáltatásbeszerzést egy szervezetbe centralizáltuk a múszaki igazgatóságon" (HUN Pharma).

\section{A kontroll}

Akkor beszélünk a kontroll centralizációjáról, ha a korábbiaknál gyakoribb vagy részletesebbé válik a beszámolás. Colignon és Covaleski (1993) szerint a változó környezet a számviteli rendszer centralizációját eredményezheti.

„Egy nagyon szigorú kontrollingot vezetett be a válságmenedzser. Korábban féléves időszakokban vizsgáltuk felül, hogy miként múködik a cég, ettől az időponttól kezdve hetente, vezetői értekezleten mutatják be az üzletágvezetók a történéseket. (...) Ez egyfelól sokkoló is volt, mert amikor még süllyedtünk, akkor hétről-hétre láttuk, hogy miként nô a veszteségünk" (HUN Metal). Azonban néha nincs ilyen drasztikus változás a kontrollingrendszerben, kizárólag a beszámolási szokások változnak meg. „A (rendszer nem változott, de a) menedzsment board viszont a rendszeres beszámoltatást már komolyabban vette, mint a válság előtt. Jobban odafigyeltek, mi is történt valójában" (HUN Engin).

A további elemzésekhez az alábbi, mindhárom típusú centralizációt magában foglaló definíciót fogjuk alkalmazni. A központosítás szintjét a vállalati döntéshozatali jogkörök koncentrációjából vezetjük le. Ha ez a koncentráció növekszik, a vállalat centralizál, ellenkezô esetben decentralizál.

\section{Érvelések a centralizáció és decentralizáció mellett}

A tanulmány következő fejezete bemutatja, hogy melyek voltak a legnépszerúbb érvek a döntéshozatali jogkörök megváltoztatása mellett. Az interjúalanyok mind racionális, mind emocionális érveket is felhoztak, melyek mélységi elemzése hozzásegíthet a központosítás és a válság közötti kapcsolat vizsgálatához.

\section{Érvek a centralizáció mellett \\ Racionális érvelés}

A legtöbb racionális logikára épító érv a hatékonysághoz kapcsolódott. „A kézi irányítás (...) válság idején nagyon hatékony tud lenni" (HUN Metal). A szervezeti struktúrák elemzése közben átváltást találunk a hatékonyság és az alkalmazkodás között (Peng, 2009). Davis et al. (2009) szimulációs modellje alapján, ha túl sok és túl kevés hierarchia között kell választanunk, akkor dinamikus környezetben érdemesebb a centralizált megoldást alkalmazni. Golden (1992) szerint a központi operatív kontroll elősegíti a költségek csökkentését, ami kulcsfontosságú reakció válságkezelés idején.
E hatékonyság az összvállalati szemléletből fakadhat, mely egy szintén népszerú érv volt a centralizáció mellett. „Szerettünk volna egy csoportszeméletet (...) ahelyett, hogy mindenki a saját piacára fókuszálva hozzon döntést a csoport többi tagjának figyelembevétele nélkül” (UK DIY). Ideálisan a központosított döntéshozatal a központba gyújt minden releváns információt, ahol a felső vezetôk az egész vállalatra optimalizálva dönthetnek (Alonso et al., 2008).

Több interjúalany kiemelte a szervezeti egységek összevonásának elónyeit is. A UK Cons felső vezetôje a központosításra és standardizálásra hozott példát: „,egészség és biztonság témakörben 20-30 különböző beszámolási rendszer múködött vállalat szerte. Most mindenki ugyanazt a rendszert alkalmazza (...) így mindenki azonnal megérti a különböző országok kimutatásait. A közös cél eléréséért egy stratégiát és egy struktúrát alkalmazunk".

A könnyebb kommunikáció volt a következő legygyakrabban említett érv a központosítás mellett. „Sokkal egyszerúbb 8 emberrel konszenzusra jutni, mint amikor 30 ember ül össze" (UK Print). Staw et al. (1984) kimutatták, hogy veszélyhelyzetben a központi döntéshozó szervek információval túlterheltek, így előnyben részesítik az egyszerúsítéseket. Sót még egy decentralizált szervezetben is kiemelkedően fontos az egységek közötti koordináció (Alonso et al., 2008), különösen, ha nem teljes a szervezeti egységek céljai közötti egyezés (Aghion - Tirole, 1997).

A következő népszerú érv a döntési sebesség növekedése volt ${ }^{2}$. „A centralizált döntéshozatal nyilvánvaló előnye, hogy rövidülnek a döntési utak" (HUN Engin). Hasonló véleményt fogalmaz meg Baum és Wally 2003-as tanulmánya, mely bemutatja, hogy miként képes a döntési sebesség támogatni a vállalati növekedést dinamikus környezetben. A HUN Metal felső vezetője egy drámai példával fejti ki a jelenséget: „Békeidőben el lehet játszani ezt a menedzsmentesdit, élesebb helyzetben nincs erre idő".

\section{Emocionális érvelés}

A legfontosabb érzelmi logikára épülő érvelés a bizalom kérdése volt. „Amikor válságban vagyunk, nem akarok senki másban megbízni. Kizárólag a saját döntésemben akarok megbízni. Hogy miért? Azt nagyon nehezen tudom megmagyarázni" (UK Light). A bizalom a delegáció legfontosabb tényezője (Aghion - Tirole, 1997; Aghion et al., 2013). Richardson et al. (2002) szerint prosperitást követően a vezérigazgató kockázat-kerülôvé válik, így kevéssé fog delegálni. Egyszerúen néha a felső vezető túl fontosnak, vagy túl bonyolultnak tart egy döntést, hogy azt kiszervezze másnak, azaz túlzottan aggódik a potenciális hibák miatt (Leana, 1987 in: Richardson et al., 2002). A HUN 
Metal felső vezetôje hasonló példát említ: „néhányan nem alkalmasak a vezetésre, mert agyonnyomja ôket a felelősség. Ettől lelassulhatnak".

Természetesen a nemzeti kultúra is befolyásolja a bizalom szintjét. A World Management Survey (20072009) szerint a multinacionális vállalatok közötti bizalom sokkal magasabb az USA és az Egyesült Királyság között, mint a brit és francia vállalatok között (Aghion et al., 2013). A brit UK DIY vállalat felső vezetőjének véleménye egybevág ezzel: „Teljesen egyértelmú volt, hogy Európa egyes részeiben (különösen Franciaországban) szocialista megközelítés dívik. Az amerikai és a brit gazdaság elég erősen növekednek, amíg az európai megrekedt. Ez többnyire a vállalkozói mentalitás hiányából fakad. Az európai hozzáállás eléggé szocialista".

A bizalom után még etikai érveket is megemlítettek a centralizáció mellett, ugyanis a UK Material felsố vezetôje szerint, ha a tulajdonosok viselik a veszteségeket, akkor megérdemlik, hogy nagyobb kontrolljogokkal bírjanak.

\section{Érvek a decentralizáció mellett}

Jóllehet a mintából csupán három vállalat decentralizált a válság alatt, azonban szinten minden felső vezetô megemlített pár mellette szóló érvet, melyek között egyaránt találunk racionális és érzelmi érveket.

\section{Racionális érvelés}

A decentralizáció mellett legtöbbször említett érv a szervezeti egységek helyi szituációjának mélyebb megértése volt. „A centralizáció legnagyobb hátránya, hogy lemond arról az elónyről, hogy a helyi vezetôk ismerik legjobban a piacokat. Nélkülük nem lehet teljesen megérteni és megoldani a helyi kihívásokat" (UK DIY). A decentralizált üzletegységek könnyebben tudnak alkalmazkodni a helyi versenykörnyezethez, mint a centralizáltak (Alonso et al., 2008). „Közvetlenül is megkereshetjük a fogyasztókat és értékesíthetnénk nekik (disztribútorok alkalmazása nélkül). Ez olcsóbb is lenne. A legnagyobb hátrány viszont az, hogy nehezen fogjuk tudni újraépíteni a piacot. A disztribútor érti a helyi piacot (új koncertek, új kulturális központok stb.), de én nem" (UK Light).

A másik kiemelt érv a felelősség megosztása volt. ,,az üzletágvezetôk bekerültek a menedzsmentbe, (...) így jobban szétosztottuk a felelósségeket. A kézi vezérlésnek az a nagy hátránya, hogy a végén a felelősség mégis a „kézi-vezérlő” vállán nyugszik” (HUN Metal). Több kutatás is bemutatta már, hogy a decentralizált szervezet ellenállóbb, mert a megosztott felelősség segít a gyorsabb alkalmazkodásban. Adams et al. (2005) kijelentik, hogy a nagyhatalmú vezérigazgatóval múködő vállalatok teljesítménye jobban szóródik, mivel nagyobb a döntési hiba kockázata a decentralizált szervezetekéhez képest. Mone et al. (1998) kutatása bemutatja, hogy a kevésbé szétosztott hatalommal rendelkezô vállalatok esetében a válság jelentősebben csök kenti a vállalati innovációt is.

A következő népszerú decentralizáció mellett szóló érv az új tudás, vagy új nézőpont a menedzsmentbe történő beemelése volt. „Nagyobb számú embert vontunk be a döntéshozatalba (...), többen hallathatták a hangjukat, így többféle input vált elérhetôvé a döntéseknél” (UK Electro). Amint azt Meyer (1982) kutatása bemutatja, a decentralizált struktúra még válság időszakában is erôsíti a szervezeti tanulást. Mi több Aghion et al. (2013) szerint a tudásintenzív vállalatok jelentôsebb termelékenységnövekedést érnek el a decentralizációt követően. Ezt az új tudás, vagy nézőpont beemelése is elóidézheti. ,a válság folyamatos volt. Úgy éreztük, hogy valami változás kell (...) ezért megalkottunk egy értékesítési menedzsmentpozíciót és felvettünk egy új kollégát. (...) Ố a legtöbb nagyobb döntésben is részt vett" (HUN Cosmet).

\section{Érzelmi érvelés}

A decentralizáció erősítheti a szervezet innovációs aktivitását is. Aghion és Tirole (1997) kifejti, hogy a delegálás legfőbb oka, hogy támogassák a szervezet alacsonyabb szintjén megjelenő kezdeményezéseket. Puga és Trefler (2002) szerint bár a központosítás segíti a megbízót az innovációs költségek féken tartásában, azonban eközben csökkenti is az ügynök újítási motivációját. „Nyilván ez különbözik cégekként és személyiségekként is. Szerintem a vállalkozói attitúdöt nehezíti, ha egy centralizált szervezetben kell dolgozni (...) mert nem üthetsz nyélbe olyan ügyleteket, amilyent szeretnél" (UK Cons).

Végül személyi tényezők is lehetnek a decentralizáció okai. A UK Cons felső vezetóje kijelentette, hogy „szerintem egyéni szempontból egy kicsit nehezebb elviselni a központosítást, ellentétben a decentralizációval". Hasonló véleményt fogalmazott meg a HUN Wheel vezérigazgatója is ,(A szúkebb, centralizált fórumokhoz képest) egy jól múködő kollektívában, vagy vezetői fórumokban jó dolgozni, mert élvezetesebb". Ső́t a centralizáció egyik legtöbbször emlegetett hátránya az volt, hogy a szervezet tagjai egyszerúen etikailag helytelenítették a központosítást ,azzal fogják támadni a felső vezetôt, hogy antidemokratikus vagy, hogy nem tartja be a szabályokat. Lám-lám, akkor sem kérdezett meg minket" (HUN Wheel).

\section{A ,meg nem említett" érvek}

$\mathrm{Az}$ alkalmazott, félig-strukturált interjúrendszer lehetőséget ad arra, hogy a meg nem említett érveket is elemezzük. A fenti elemzés azon tényezőket összegezte, 
melyeket legalább egy felső vezetô legalább egyszer megemlített. Fontos kiemelni, hogy sem az interjú alatt, sem előzetesen nem tájékoztattam az interjúalanyokat a centralizációs irodalom eredményeiről. Ezért érdekes lehet elemezni azt is, hogy melyek azok az érvek, melyek ugyan a szakterületen már régóta kutatottak, de egyáltalán nem került szóba a 45-90 perc hosszúságú interjúk során.

\section{Innováció vs. centralizáció}

Mint azt már korábban áttekintettük, a szervezeteknek szembe kell nézniük azzal a kihívással, hogy átváltás van a hatékonyság és az alkalmazkodás között (Peng, 2009). Habár szinte az összes felső vezető kiemelte a központosítás hatékonyságnövelő hatását, egyikük sem beszélt annak innovációcsökkentő következményéről. Kizárólag egy interjúalany (UK Cons) említette, hogy a vállalkozó attitúddel rendelkező személyek nem kedvelik a központosítást. Aghion és Tirole (1997) kifejtik, hogyha az ügynök részt vehet a döntéshozatalban, akkor motiváltabbá válik. Más szemszögből láthatjuk, hogyha egy korábban beavatott ügynöktól centralizáció eredményeképpen elveszik a döntési jogköröket, akkor az még kevésbé lesz elhivatott és proaktív, mint korábban. Ezáltal a vállalat veszthet az innovációs készségéből. Természetesen egyik oldalról a válság alatt csökken a beruházható tôke mennyisége, így nem is annyira aktuális az innováció, mint korábban. Másrészről viszont figyelmeztető jel, hogy a mintában szereplő menedzserek mennyire nem emlékeztek meg a központosítás e hátrányáról.

\section{A központosítás költségei}

A monitorozás és az információkezelés mindig generál költségeket (Aghion et al., 2013). Az ösztönzéselmélet szerint a delegáció célja a szervezet alacsonyabb szintjein létrejövő kezdeményezések támogatása. E legnagyobb kihívását az jelenti, hogy habár a kontroll jelentôs költségeket generálhat, a szervezeti központ ideje és figyelme nincs beárazva (Aghion - Tirole, 1997). Érdekesség, hogy mindössze egyetlen felsô vezetô beszélt a központosítás költségeiről, de ő is csak azt említette meg, hogy az anyavállalatuk növelte a centralizációt, így nekik kellett több erőforrást fordítani a szigorúbb beszámolásra. Egyetlen centralizáló interjúalany sem említette, hogy a beosztottakra ez extra terhet rótt volna, vagy hogy a szervezetnek költséges átalakításon kellett volna átesnie.

Ezt több tényező is magyarázhatja. (1) Mivel a külső tevékenységeket mindig könnyebb árazni, mint a vállalaton belülieket (Aghion - Tirole, 1997), így talán a vezetők nem mindig vették figyelembe a központosítás megnövekedett költségeit. (2) Mi több néha a megbízó és az ügynök egyaránt szeretné a másikra hárítani e költségeket (Puga - Trefler, 2002), így lehet, hogy nem volt egyértelmú ki viseli a centralizáció költségeit. (3) Valamint természetesen az is lehetséges, hogy egyszerúen nem emlékeztek erre a tényezőre.

\section{A központosítás hatalmi aspektusai}

Természetesen minden átalakítás hatalmi kérdéseket is felvet (Pfeffer - Lebleici, 1973), ez különösen igaz centralizáció esetén. A központosítással kapcsolatban szinte egy vezető sem említett bármilyen hatalmi küzdelemhez, vagy szervezeti ellenálláshoz köthetô tényezốt, melyek eléggé ártalmasak lehetnek válságidőszakban (Marin - Verdier, 2008). Vagy hamar leküzdték az ellenállást, vagy csak egyszerúen nem szívesen beszéltek róluk interjúszituációban.

\section{Hosszú távú következmények}

Habár az átalakítás hosszú távon befolyásolja a szervezeteket, csak kevés felsô vezető beszélt róluk mélyebben. Az összes okot és következményt kizárólag rövidtávon elemezték, ső́t magára a centralizációra is csak átmeneti megoldásként hivatkoztak. Természetesen az is lehet, hogy igenis megfontolták a hosszú távú következményeket, csak ezeket az interjúk során nem említették meg.

\section{A válság és a centralizáció összefüggése}

Az interjúkutatás alapján a központosítást a válságra adott reakcióként értékelhetjük. A legtöbb felső vezetô nem említette meg a válságmenedzsment-taktikák között a centralizációt. Legtöbbször akkor emlékeztek vissza rá, amikor szembesítettem őket az EFIGE-kérdőívben adott válaszukkal (t.i. centralizáltak, vagy decentralizáltak). Ezek után minden centralizáló interjúalany közvetlenül összekötötte a központosítást a válsággal. A kifejtés során vált nyilvánvalóvá, hogy a menedzserek különböző centralizáció definíciót alkalmaznak, melyek mindegyike köthetô a válságreakciókhoz.

A de facto központosítás relatíve könnyen megvalósítható. Például a felső vezető a továbbiakban egyszerúen csak nem von be másokat a döntéseibe. Nem meglepó módon ez volt az egyik legnépszerúbb centralizációs forma. Egy kissé bonyolultabb, ám még mindig egyszerúen megoldható a kontroll centralizációja. Ez esetben a menedzsment új riportokat igényelhet, vagy a meglévóket kérheti gyakrabban. E megoldásnak valamennyivel magasabbak a tranzakciós költségei, de még így is a megnövekedett költségek legnagyobb részét a riportkészítő beosztottak viselik (különösen rövid távon).

A de jure centralizáció magában foglalja a vállalatirányítási rendszer átalakítását, mely nagy mennyiségú adminisztratív költséget jelent és csak hosszabb távon kecsegtet „megtérüléssel”. Emiatt ez egy viszonylagosan bonyolult formája a döntési jogkörök koncent- 
rálásának. Azonban a leginkább kihívást jelentő központosítási forma a végrehajtás centralizációja, mely megköveteli a szervezet átalakítását is.

Következésképpen még azon vállalatok is centralizálhattak, melyek nem hajtottak végre komplex szervezeti átalakítást. Sót, a központosítás bizonyos formái (de facto és kontroll) oly egyszerúen megvalósíthatóak, hogy egy ideig talán fel sem túnik a szervezet nagy részének.

Míg a centralizáló vállalatok összekötötték döntésüket a válsággal, egyetlen decentralizáló sem emelt ki bármilyen közvetlen kapcsolatot a recesszió és a delegálás között.

A három delegáló vállalat közül kettő egy elég intenzív növekedési periódus közepén voltak a válság kitörésekor. Emiatt a decentralizáló lépésük (új középvezetői szerepek kialakítása) sokkal inkább a korábbi prosperitáshoz köthetô semmint a recesszióhoz. A harmadik vállalat egy évek óta, hosszan elnyúló árbevétel-csökkenési folyamat során decentralizált 2009 körül. Elmondásuk szerint az EU-csatlakozás sokkal inkább érintette őket, mint a Jelzáloghitel Válság (HUN Cosmet). Mi több, az első két decentralizáló a recesszió elsô hullámát követő pár évben, egy újabb válsággal nézett szembe, melynek következtében ismét centralizált.

A korábbi kutatások számos érvet hoznak fel a válság alatti decentralizáció mellett. Például a decentralizált szervezet még recesszió idején is erósíti a szervezeti tanulást (Meyer, 1982). Aghion és Tirole (1997) kifejti, hogy ha sürgősen kell döntéseket hozni (pl. válság idején) az ellenőrzési költségek nagysága miatt érdemesebb delegálni. Ezen interjúkutatás eredményei azonban azt mutatják, hogy a legtöbb vállalat nem a válság hatására decentralizál. Ellenkezőleg a recesszió a központosítás egy alapvető indoka volt.

Természetesen ezek az eredményeket óvatosan kell kezelnünk. Talán a felső vezetôk nem emlékeztek megfelelően (hisz majd öt éve történtek az események). Talán a mintát kellene újabb iparágakra, vagy országokra kiterjeszteni. De e kutatás fó üzenete, hogy a gazdasági ciklusok és a döntési jogkörök változása a következőképpen függ össze: a válság növeli a centralizáció esélyét. Lehetséges, hogy találunk ellenpéldákat is, de ez a kauzalitás fó iránya.

A tanulmány e fejezete a központosítás legfontosabb, gyakorlatban felmerült érveit elemezte, a következő rész azonban egy elméleti megközelítést mutat be. $\mathrm{Az}$ interjúkra építve konkrét adatokkal rendelkezünk a központosításról, valamint ellentétéról, a decentralizációról. Továbbá mivel nemcsak a válság, hanem a fellendülés is megjelent az interjúkban (lásd a két decentralizátor növekedési előzményeit), így érdekes lehet a recesszió ellentétére is kiterjeszteni az elemzést. A következő modell a centralizáció és a válság területéről sok információval bír, elfogadható mennyiségú adattal rendelkezik a decentralizáció területéról, azonban a fellendülés jelenségéről kevés a gyakorlati tapasztalata. Emiatt fontos kiemelni, hogy a következő fejezet tartalma egy elméleti sejtés csupán, melynek bizonyítása további kutatásokra marad.

\section{A centralizáció mint a ciklusokhoz való alkalmazkodás stratégiája}

A nagyobb bizonytalanság miatt a vállalatvezetók válság alatti kontrolligénye megnövekszik. Aghion és Tirole (1997) szerint, ha a megbízó túlterhelt, akkor a döntéshozatali jogokat átstrukturálja. Ezt láthatjuk a recesszió alatt, hisz a normál üzletmenet mellett még a válságot is kezelniük kell a vezetóknek. Mindemellett a központi döntéshozó szervek nehéz helyzetekben támogatják az egyszerúsítéseket a döntéshozatal során (Staw et al., 1984). Sőt, Puga és Trefler (2002) levezetik, hogy a centralizált szervezetek jobban teljesítenek a költségkontroll területén, ami oly fontos recesszió idején.

Másrészről fellendülés idején a vállalatok flexibilitásra törekednek, hogy jobban tudjanak alkalmazkodni a kifejlődő üzleti lehetőségekhez. Alonso et al. (2008) kifejtik, hogy a decentralizált szervezet azért jobb a rugalmasságban, mert az üzletágvezetők jobban ismerik a helyi információkat és mivel megfeleló döntési jogkörökkel rendelkeznek, így gyorsabban tudnak reagálni a központosított szervezetekhez képest. Emiatt a decentralizált vállalatok könnyebben innoválnak (Mone et al., 1998) és magasabb árbevétel- és termelékenységnövekedést képesek elérni a centralizáltakhoz képest $(\mathrm{Ag}$ hion - Bloom, 2014).

Következésképpen megfogalmazhatjuk a centralizációs ciklus sejtést, mely szerint a válság hatására centralizálnak a vállalatok, míg fellendülés idején decentralizálnak. De természetesen a valóság mindig komplexebb, az ilyen egyszerúsített elméleteknél.

\section{Tökéletlen alkalmazkodás a ciklusokhoz}

„Szerintem a válság nagyobb központosítást eredményezet, mint amire az embereknek valóban szükségük volt a helyzet kezeléséhez" (UK Cons). Amint azt a UK Cons felső vezetője is kiemelte centralizáció szempontjából a ciklusokhoz történő alkalmazkodás nem mindig tökéletes. A központosítás előnyös lehet válság idején, de lassíthat a fellendülés alatt és vica versa a decentralizáció esetén. A tanulmány következő része egy olyan elméleti modellt állít fel, mely bemutatja, hogy a vállalatok miként alkalmazkodnak a gazdasági ciklusokhoz a központosítás szemszögéből.

A nem megfelelő centralizáció több tényezőben is megnyilvánulhat. Ezek többek között a centralizáció (1) időbelisége, (2) mértéke, (3) kiterjedése és típusa. A 
centralizáció időbelisége azt fejezi ki, hogy a vállalatok nem a ciklusoknak megfelelóen központosítanak, vagy delegálnak, hanem csak késve. A központosítás mértékében úgy jelenhet meg a tökéletlen alkalmazkodás, hogy egyes vállalatok kevésbé súlyos válság esetén is nagyon szigorú központosítást végeznek, vagy épp ellenkezőleg, a fellendülés erőssége szempontjából indokolatlan mértékben decentralizáltnak.

Végül ide tartozhat a központosítás nem megfeleló típusa és kiterjedése is. Lehetséges, hogy kizárólag egy üzletágat érint a recesszió, viszont a felső vezetô az egész szervezetben központosítást végez. Ehhez hasonló példa, amikor bár a környezet változása a végrehajtás centralizációját indokolná (pl. szervezeti egységek öszszevonása), mégis másik típusú központosítást végez a vállalat (pl. a vállalati irányítási rendszer átszervezése). Mivel a ciklusokhoz való alkalmazkodás kulcstényezôje az időben történő reakció, ezért az alábbi fejezet a központosítás időbeliségét írja le (l.ábra).

\section{A centralizáció és a gazdasági ciklusok általános modellje}

Az alábbi modell három fó elemból áll: (1) a gazdasági helyzet észlelése, (2) kognitív folyamatok, (3) a gazdasági helyzetre történő reakció. E modell kizárólag a gazdasági helyzetben bekövetkező radikális változáso- kat kezeli: a válságot és a fellendülést. A köztes, stabil állapotot más dinamika vezérli, ezért ezzel most nem foglalkozunk. Az elemzés központjában a vállalat felsővezetője áll, aki miután észleli a gazdasági helyzetet, kognitív folyamatok során értékeli azt, majd dönt a reakciókról (centralizál vagy decentralizál).

A gazdasági helyzet észlelése. A modell elsô eleme azt elemzi, hogy milyen érzékelókön keresztül észleli a vállalat a gazdasági helyzetet. A komplexitás kezelése végett mindösszesen két típusú észlelést különböztetünk meg: tökéletes és tökéletlen észlelést. Az első leginkább a homo eoconomicus emberképhez áll a legközelebb: itt a felső vezető tökéletesen érzékeli a környezetét. Ennek során azonnal észleli a változásokat, mely inputul szolgál a tökéletesen illeszkedő előrejelzési modelljéhez. Ezzel szemben a tökéletlen észleléssel bíró felső vezetô nem képes azonnal, tökéletesen megérteni a környezet változásait. Sót, a fellendülést mindig nehezebb észlelni, mint a válságot. „Mindig a tendencia számít, így egy hónap, vagy hónapon belüli mozgás nem olyan fontos, de amikor már a harmadik hónapban is növekedés látható, akkor arra már lehet valamit mondani" (HUN Engin). Mivel a válság során jelentős és koncentrált forgalom-visszaesés tapasztalható, ezért ezt mindig könnyebb azonosítani, mint egy lassabb, inkrementális fellendülést.

A ciklusokhoz történő tökéletlen centralizációs alkalmazkodás elméleti modellje

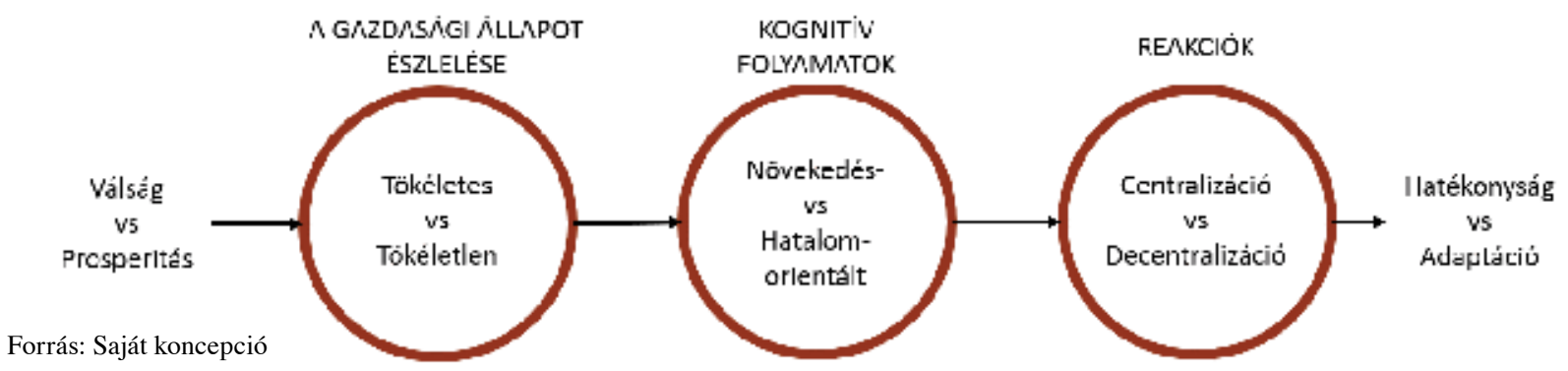

Kognitív folyamatok. Ez a modellelem a felső vezetők radikális környezeti változáskor alkalmazott domináns gondolkodásmódját jelzi. A növekedésorientált logika esetén a menedzser úgy véli, személyes hasznai akkor a legmagasabbak, ha a vállalatét is maximálja. Emiatt kalkulatív logikát alkalmaz; t.i. minden olyan változtatást végrehajt, mely növeli a vállalat profitabilitását. A másik lehetséges megoldás a hatalomorientált logika alkalmazása, melynek lényege, hogy a vezető abban hisz, hogy kizárólag a vállalaton belüli személyes hatalma biztosíthatja a saját hasznainak maximá- lását. Emiatt mindig motivált lesz abban, hogy a lehető legtovább fenntartsa a vállalaton belüli személyes döntéshozatali jogköreit.

A gazdasági helyzetre történő reakció. Mint azt már korábban láthattuk, rengeteg válságstratégiát különböztethetünk meg, azonban jelenlegi modellünkben mindössze két reakció lehetséges: centralizáció vagy decentralizáció. A központosítás alatt a vállalaton belüli döntéshozatali jogkörök koncentrálódását értjük, a decentralizáció alatt pedig az ellenkezőjét ${ }^{3}$. 
A modell három alkalmazkodási módot különböztet meg, melyek a következők: (1) ,a tökéletes alkalmazkodó", (2) a korlátozottan racionális, valamint (3) a hatalmi döntéshozó ${ }^{4}$ (2. ábra).

\section{A „tökéletes alkalmazkodó”}

Ez esetben a felső vezető tökéletesen észleli az aktuális gazdasági helyzetet és növekedésorientált logikát alkalmaz. Az első válsághoz köthető forgalom-viszszaesést is megérzi és megérti, hogy elkezdődött a recesszió. Hasonló módon érzékeli a fellendülés első hullámát és azonnal észleli, hogy beköszönt a valódi prosperitás.

Mivel racionális kognitív folyamatokkal bír, így érti, hogy a recesszió idején erős költségkontrollra van szüksége a szervezeti bizonytalanság kezelése végett. Emiatt centralizálni fog, hogy növelje a vállalat hatékonyságát. A fellendülés során pedig tudja, hogy az üzletágvezetők gyorsabban tudják növelni az innovációs kapacitást, illetve a profitabilitást, mint ő egymaga, emiatt decentralizálni fog.

\section{A „korlátozottan racionális döntéshozó”}

Itt a felső vezető nem képes azonnal észlelni a gazdasági változásokat. Nem tudja, hogy a legutóbbi jelentés által jelzett forgalom-visszaesés csak átmeneti lassulást jelent, vagy ez az első lépés egy katasztrofális összeomlás felé. Hasonló problémával szembesül a fellendülés idején is. Növekedésorientált kognitív folyamatokat alkalmaz, így a vállalati profitot szeretné maximalizálni, de addig nem szeretne lépni, amíg nem lesz teljesen biztos a jövőbeli trendekben. Mikor biztos lesz a válság kitörésében, azonnal centralizálni fog, hogy növelje a hatékonyságot. Másrészről a fellendülésben növelni szeretné a flexibilitást, így decentralizál. Azonban mivel később észlelte a változó trendeket a centralizációs alkalmazkodást is később kezdi meg.

2. ábra

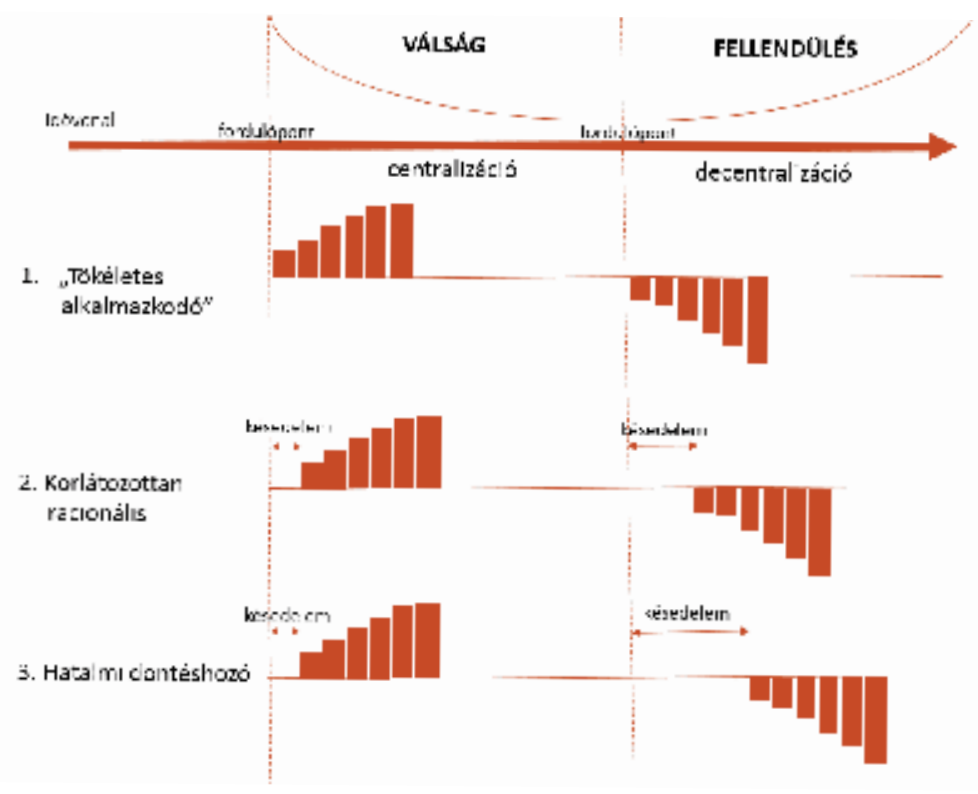

Mi több, amint azt korábban láthattuk a prosperitást nehezebb észlelni a válságnál, így a fellendülés esetén még később fog decentralizálni. Végeredményként valamennyivel tovább fent fogja tartani a centralizációt, mint azt a környezeti változások indokolnák. „Amikor már hittünk benne, hogy valóságosan is elindul a progresszió, akkor lazítottunk a központi döntéseken. Szerintem egy negyed-félév késéssel visszatértünk a korábbi (decentralizált) állapothoz" (HUN Engin).

\section{A ,hatalmi döntéshozó”}

Ebben az esetben a felső vezető nem képes tökéletesen érzékelni a gazdasági trendeket és dominánsan hatalomorientált kognitív folyamatokat alkalmaz. Így a korábbiakhoz hasonló dilemmával szembesül: időre van szüksége, míg megérti a változó trendeket. Miután biztos a gazdasági helyzet alakulásában, csak azután kezdi megfontolni a potenciális reakciókat. Mivel érzelmi kognitív folyamatokat alkalmaz, így szereti a hatalmat, melyrôl úgy tartja, hogy ez biztosítja egyéni 
hasznai maximalizálását. Emiatt válság idején centralizál, mert nem bízik abban, hogy a kollégái képesek lennének megfelelően reagálni a recesszióra.

Másrészrő́l sokkal később fog decentralizálni két ok miatt is: (1) mert a fellendülést később észleli, mint a válságot, valamint (2) igyekszik minél tovább fenntartani személyes hatalmát. ,,(Egy decentralizációs programot követően) mi is egy kicsit visszanyúltunk a kézi irányítási rendszerhez az elnyúló válság miatt. Most egy kicsit furcsa mixben vagyunk. (...) De vissza fogunk térni, amikor az eredmények azt mutatják, hogy lehet" (HUN Metal).

A tanulmány e része leírta, hogy mi magyarázhatja a gazdasági ciklusokhoz történő tökéletlen alkalmazkodást és, hogy a vállalatok miért tartják fent a centralizációt tovább, mint az ideális. Természetesen ezek súlyos következményekkel járhatnak a profitabilitás szempontjából is, mely túlmutat e tanulmány keretein.

\section{További kutatási irány: az adaptációs elöny}

Az előző fejezet leíró módon mutatta be a tökéletlen alkalmazkodás hátterét. De mivel a döntéshozatali jogkörök befolyásolhatják a teljesítményt, ezért normatív megközelítéssel is elemezhetnénk a kérdéskört. Ennek alapja a centralizáció természetéhez köthető. Mivel a központosítás növeli a hatékonyságot, a decentralizáció pedig az innovációt, ezért a megfelelő idôzítésú változtatás versenyelónyt jelenthet a versenytársakkal szemben.

E változtatást adaptációs előnyként értelmezhetjük, mely széles körben tárgyalt az irodalomban. Idekapcsolódik Hamel és Valikangas (2003, p. 54.) reziliencia fogalma is. A stratégiailag reziliens vállalatok már azelőtt képesek profitabilitásukat lényegesen befolyásoló változtatásokra, mielőtt azok elkerülhetetlenek lennének. Mint láthatjuk a reziliencia egy jóval tágabb fogalom, azonban az időben történő (de)centralizáció egy eszköz lehet a szervezeti alkalmazkodás elérésében.

Starr et al. (2003) szerint a reziliensebb vállalatok olcsóbban juthatnak tőkéhez, mint versenytársaik. Ahhoz, hogy ezt elérjük, időben kell tudnunk alkalmazkodni a gazdasági ciklusokhoz. Ahogy azt Teece (2007) is kifejti a dinamikus képességek kifejlesztésének az egyik legfontosabb lépése, hogy hatásos érzékelô mechanizmusokat alakítsunk ki a vállalatban, mely észleli a jövő üzleti lehetőségeit. Tehát, ha egy vállalat gyorsabban észleli a környezeti változásokat (pl. válság vagy fellendülés), akkor versenyelőnyt szerezhet.

A sikeres változásmenedzsment-stratégiák végrehajtásához több sikertényezőre is figyelnünk kell (Kotter, 1995). És habár válság idején könnyebb felkelteni a változás igényét (Hemp - Stuart, 2004), Beer és Nohria (2000, p. 133.) szerint a szervezeti átalakítások közel $70 \%$-a kudarcot vall. A változást nagyban segítheti a szervezet támogatása, melyet hatalmi csatározások övezhetnek (Pfeffer - Leblebici, 1973). Így, ha azok a vállalatok, melyek képesek kezelni e küzdelmeket, könnyebben változtathatnak. Természetesen e jelenségek csak sejtések, melyek bizonyítása késóbbi kvalitatív vagy kvantitatív kutatásokra marad.

\section{Konklúzió}

E tanulmány elsődleges célja az volt, hogy megértse, miért centralizálnak a vállalatok válság idején. A következőkben a főbb következtetéseket közöljük.

\section{A csökkenó profitabilitás a vállalatokat közpon- tosításra ösztökéli.}

A racionális megközelítés szerint a centralizáció nagyon hasznos recesszió idején, hisz a vállalatok könynyebben képesek költségeiket kontrollálni, illetve növelni hatékonyságukat (Alonso et al., 2008). Erre több példát is láthattunk, amikor a vállalatvezetôk amellett érveltek, hogy válságidôszakban a gyorsabb döntéshozatal és az összvállalati szemlélet nyújthat elónyt.

Másrészrốl a központosítást az érzelmi logika is erôsítheti, ugyanis a bizonytalanság növekedése pánikot és szorongást okozhat, mely szintén a kontroll növelésére sarkall. Mi több e centralizáció tovább is fennmaradhat, ha a felsô vezető nem képes időben észlelni a környezeti változásokat (pl. fellendülés kezdetét), vagy ha ragaszkodik hatalmához. Ide sorolhatjuk azokat a példákat, amikor a vállalatvezetők azért centralizáltak, mert nem bíztak abban, hogy munkatársaik képesek kezelni a megváltozott környezetet.

\section{A felső vezetók kevésbé veszik figyelembe a köz- pontositás hosszú távú következményeit.}

Habár rengeteg tanulmány kiemeli a decentralizáció általános és különösen válságidőszakban kifejtett előnyeit (innováció, termelékenységnövekedés), azok kevéssé kerülnek előtérbe a centralizációról szóló döntés meghozatalánál. E kutatás alig talált olyan interjúalanyt, aki közvetlenül utalt arra, hogy a központosítással csökken az innovációs készség.

Ezt a veszteségkerülés jelenségével is magyarázhatjuk (Kahnemann, 2011). Ahogy azt korábban is láttuk a vállalatvezetôk válságidőszakban előnyben részesítik a költségcsökkentést, melynek kedvez a centralizáció. Azonban a költségcsökkentés által ösztökélt központosítás sokkal gyorsabb előnyökkel kecsegtet, mit a kockázatosabb, árbevételnövelés-orientált decentralizáció. Ezáltal a centralizáció gyorsabb és biztosabb eredményt jelent, mint a jövőbeli innovációkat ígérô delegálás. Emiatt válság hatására a rövid távú centralizáció lesz a kedveltebb út a vállalatok számára. 


\section{A megfelelö idôzitésú (de)centralizáció versenye- lónyt jelenthet.}

Ha a vállalatok válság idején centralizálnak, és fellendülés idején decentralizálnak, a ciklushoz való alkalmazkodás kulcsfontosságú lesz. Az a vállalat szerezhet elónyt, mely a versenytársainál gyorsabban és jobban észleli a gazdasági helyzet változásait, illetve képes átalakítani vállalata döntéshozatali jogköreit. Ide tartoznak azon vállalatok példái, akik a fellendülés kezdete után pár hónappal decentralizáltak. Ellenpéldaként pedig azokat idézhetjük fel, akik nem kezdtek el delegálni akár több évvel a fordulatot követôen sem.

A fejlett controllingrendszer segíthet a fordulópontok azonosításában, valamint az erós önreflexió támogathatja a hatalmi harcok elkerülését az átalakítások során. Természetesen ilyen készségek kiépítésénél kulcsfontosságú a menedzsment jártassága. Sót Aghion és Bloom (2014) kimutatta, hogy létezik korreláció a képzett menedzserek és a decentralizált szervezetek között, azonban az okság irányát mindmáig homály fedi.

\section{Lábjegyzet}

${ }^{1}$ Érdekes módon az ipari vállalatok 10-20\%-a jobb teljesítményt ért el 2009-ben, mint korábban (Békés et al., 2011, p. 4.).

${ }^{2}$ Érdekes módon még az a vállalati vezető is megemlítette a döntéshozatali sebesség növelésének igényét, aki később kifejtette, hogy a kereslet csökkentése miatt sokkal jobban ráértek, mint korábban (HUN Metal).

${ }^{3}$ E modell nem kezeli a centralizáció eredeti szintjét, mindössze annak változását. Elméleti feltevése, hogy a központosításnak mindössze (ember)jogi és kognitív korlátai vannak. A változást egy skálán elemezzük, melynek egyik végén a tökéletes zsarnoki uralom áll, a másikon pedig a lasseiz fair piac.

${ }^{4}$ Elméletileg létezhetne egy negyedik alkalmazkodási mód, a tökéletesen észlelö, hatalmi-döntéshozó típusa. Azonban mivel a homo eoconomicus nem kezeli a hatalomorientáltság azt a szintjét, amit az imént definiáltunk, ezért ezt a módot kizárjuk a vizsgálatunkból.

\section{Felhasznált irodalom}

Adams, R. B. - Almeida, H. - Ferreira, D. (2005): Powerful CEOs and Their Impact on Corporate Performance. The Review of Financial Studies, 18: p. 1403-1432. http://dx.doi.org/10.1093/rfs/hhi030

Aghion, P. - Bloom, N. - Van Reenen, J. (2013): Incomplete Contracts and the Internal Organization of Firms. Working Paper. Downloaded: http://web.stanford.edu/ nbloom/w18842.pdf 24 ${ }^{\text {th }}$ October 2015.

Aghion, P. - Bloom, N. (2014): Never Waste a Good Crisis? Growth and Decentralization in the Great Recession Preliminary. Downloaded: http://www. people.hbs.edu/rsadun/GoodCrisis_December2014. pdf $24^{\text {th }}$ October 2015.

Aghion, P.-Tirole, J.(1997): Formal and Real Authority in Organisations. The Journal of Political Economy, 105(1): p. 1-29. http://dx.doi.org/10.1086/262063
Alonso, R. - Dessein, W. - Matouschek, N. (2008): When Does Coordination Require Centralisation? The American Economic Review, 98: p. 145-179. http://dx.doi.org/10.1257/aer.98.1.145

Altomonte, C. - Aquilante, T. (2012): The EU-EFIGE/BRUEGEL-UNICREDIT Dataset. Bruegel Working Paper. Downloaded: http://www.bruegel.org/publications/publication-detail/publication/753-the-eu-efigebruegel-unicredit-dataset/ $24^{\text {th }}$ October 2015.

Argyres, N. S. - Silverman, B. S. (2004): R\&D, Organisation Structure, and the Development of Corporate Technological Knowledge. Strategic Management Journal, 25: p. 929-958. http://dx.doi.org/10.1002/ smj.387

Bakonyi Z. (2015): The Effect of Economic Crisis on Centralisation of Strategic Decisions. Conference Proceeding. Strategic Management Society, St Gallen, May 28-30, 2015.

Barker, I. - Vincent, L. - Duhaime, I. M. (1997): Strategic Change in the Turnaround Process: Theory and Empirical Evidence. Strategic Management Journal, 18: p. 13-38. http://dx.doi.org/10.1002/(SICI)1097-0266(199701)18:1<13::AID-SMJ843>3.0. $\mathrm{CO} ; 2-\mathrm{X}$

Baum, J. R. - Wally, S. (2003): Strategic Decision Speed and Firm Performance. Strategic Management Journal, 24: p. 1107-1129. http://dx.doi.org/10.1002/ smj.343

Beer, M. - Nohria, N. (2000): Cracking the Code of Change. Harvard Business Review, 78: p. 133-141.

Békés G. - Halpern L. - Koren M. - Muraközy B. (2011): Still standing: how European firms weathered the crisis and The third EFIGE policy report. BRUEGEL BLUEPRINT SERIES. Downloaded: http://www.bruegel.org/publications/publication-detail/publication/661-still-standing-how-european-firms-weathered-the-crisis-the-third-efige-policy-report/ $24^{\text {th }}$ October 2015.

Child, J. (1972): Organisation Structure and Strategies of Control: A Replication of the Aston Study. Administrative Science Quarterly, 17: p. 163-177. http:// dx.doi.org/10.2307/2393951

Cohen, I. - Lachman, R. (1988): The Generality of Strategic Contingencies Approach to Sub-unit Power. Organisational Studies, 9: p. 371-391. http://dx.doi. org/10.1177/017084068800900305

Colignon, R. - Covaleski, M. A. (1993): Centralisation of the Strategic Planning And Control Process In A High-Technology Firm : A Case Study. Journal of Management Issues, 5(3): p. 353-372.

Cosgrave, J. (1996): Decision making in emergencies. Disaster Prevention and Management, 5(4): p. 2835. http://dx.doi.org/10.1108/09653569610127424 
Davis, J.P. - Eisenhardt, K.M. - Bingham, C. B. (2009): Optimal Structure, Market Dynamism, and the Strategy of Simple Rules. Administrative Science Quarterly, 54: p. 413-452. http://dx.doi.org/10.2189/ asqu.2009.54.3.413

Eisenhardt, K. M. - Graebner, M. E. (2007): Theory building from cases: Opportunities and challenges. Academy of Management Journal, 50(1): p. 25-32. http://dx.doi.org/10.5465/AMJ.2007.24160888

Fruk, M. - Hall, S. - Mittal, D. (2013): Never let a good crisis in waste. McKinsey Quarterly, 49: p. 1-4.

Gates, S. R. - Egelhoff, W. G. (1986): Centralisation in Headquarters-Subsidiary Relationships. Journal of International Business Studies, 17: p. 71-92. http:// dx.doi.org/10.1057/palgrave.jibs.8490425

Golden, B. R. (1992): SBU Strategy and Performance: The Moderating Effects of the Corporate-SBU Relationship. Strategic Management Journal, 13: p. 145-158. http://dx.doi.org/10.1002/smj.4250130206

Hage, J. - Dewar, R. (1973): Elite Values versus Organisational Structure in Predicting Innovation. Administrative Science Quarterly, 18: p. 279-290. http://dx.doi.org/10.2307/2391664

Hall, S. - Kehoe, C. (2013): How quickly should a new CEO shift corporate resources? McKinsey Quarterly, October

Hamel, G. - Välikangas, L. (2003 The Quest for Resilience. Harvard Business Review, 81(9): p.): 52-65.

Hemp, P. - Stewart, T. A. (2004): Leading Change When Business Is Good. Harvard Business Review, 82: p. 60-70.

Higgins, G. - Freedman, J. (2013): Improving decision making in crisis. Journal of Business Continuity \& Emergency Planning, 7: p. 65-76.

Kahneman, D. (2011): Thinking, Fast and Slow. New York: Macmillan: p. 1-512.

Keats, B. W. - Hitt, M. A. (1988): A Causal Model of Linkages among Environmental Dimensions, Macro Organizational Characteristics, and Performance. The Academy of Management Journal, 31: p. 570598. http://dx.doi.org/10.2307/256460

Kotter, J. P. (1995): Leading Change - Why Transformation Efforts Fail. Harvard Business Review, 73: p. 60-67.

Kunc, M. - Bhandari, R. (2011): Strategic development processes during economic and financial crisis. Management Decision, 49: p. 1343-1353. http://dx.doi. org/10.1108/00251741111163151

Kunisch, S. - Schimmer, M. - Müller-Stewens, G. (2012): A new look for the head office : corporate headquarters redesigns during times of crisis. Performance, 4(4): p. 10-21.

Lin, X. - Germain, R. (2003): Organisational Structure, Context, Customer Orientation, and Performance:
Lessons from Chinese State-Owned Enterprises. Strategic Management Journal, 24: p. 1131-1151. http://dx.doi.org/10.1002/smj.348

Ling, Y. - Simsek, Z. - Lubatkin, M. H. - Veiga, J. F. (2008): Transformational Leadership's Role in Promoting Corporate Entrepreneurship: Examining the CEO-TMT Interface. The Academy of Management Journal, 51: p. 557-576. http://dx.doi.org/10.5465/ AMJ.2008.32626023

Marin, D. - Verdier, T. (2008): Power inside the Firm and the Market: A General Equilibrium Approach. Journal of the European Economic Association, 6(4): p. 752-788. http://dx.doi.org/10.1162/ JEEA.2008.6.4.752

Mason, J. (2006): Mixing methods in a qualitatively driven way. Qualitative Research, 6(1): p. 9-25. http://dx.doi.org/10.1177/1468794106058866

Meyer, A. D. (1982): Adapting to Environmental Jolts. Administrative Science Quarterly, 27(4): p. 515-537. http://dx.doi.org/10.2307/2392528

Mone, M. A. - McKinley, W. - Barker, V. L. I. (1998): Organisational Decline and Innovation: A Contingency Framework. The Academy of Management Review, 23: p. 115-132.

Nohria, N. - Ghoshal, S. (1994): Differentiated Fit and Shared Values: Alternatives for Managing Headquarters-Subsidiary. Strategic Management Journal, 15: p. 491-502. http://dx.doi.org/10.1002/ smj.4250150606

OECD (2012): Innovation in the crisis and beyond. OECD Science, Technology and Industry Outlook, 2012: p. 21-57. Downloaded: http://www.oecd.org/ sti/sti-outlook-2012-highlights.pdf 24th October 2015.

Peng, M. W. (2009): Global Strategic Management. Thousand Oaks: Cengage Learning: p. 1-510.

Pfeffer, J. - Leblebici, H. (1973): The Effect of Competition on Some Dimensions of Organisational Structure. Social Forces, 52: p. 268-279. http://dx.doi. org $/ 10.1093 / \mathrm{sf} / 52.2 .268$

Puga, D. - Trefler, D. (2002): Knowledge Creation and Control in Organizations. Working Paper. Downloaded: http://diegopuga.org/papers/know.pdf 24th October 2015.

Reinhart, C. M. - Rogoff, K. S. (2009): This Time is Different Eight Centuries of Financial Folly. Princeton, NJ.: Princeton University Press: p. 1-463.

Richardson, H. A. - Amason, A. C. - Buchholtz, A. K.Gerard, J. G. (2002): CEO Willingness to Delegate to the Top Management Team: The Influence of Organisational Performance. The International Journal of Organisational Analysis, 10: p. 134-155. http://dx. doi.org/10.1108/eb028947

Selmier, W.T.-Newenham-Kahindi, A.M.-Oh, Ch.H. 
(2015): Understanding the Words of Relationships: Language as an Essential Tool to Manage CSR in Communities of Place. Journal of International Business Studies, 46(2): p. 153-179. http://dx.doi. org/10.1057/jibs.2014.58

Smart, C. - Vertinsky, I. (1984): Strategy and the Environment: A Study of Corporate Responses to Crises. Strategic Management Journal, 5: p. 199-213. http://dx.doi.org/10.1002/smj.4250050302

Starr, R. - Newfrock, J. - Delurey, M. (2003): Enterprise resilience: managing risk in the networked economy. Strategy and Business, 30: p. 70-79.
Staw, B. M. - Sandelands, L. E. - Dutton, J. E. (1984): Threat-Rigidity Effects in Organisational Behaviour: A Multilevel Analysis. Administrative Science Quarterly, 26: p. 501-524. http://dx.doi. org/10.2307/2392337

Teece, D. J. (2007): Microfoundations of (Sustainable) Enterprise Performance. Strategic Management Journal, 28: p. 1319-1350. http://dx.doi.org/10.1002/smj.640

Wilson, J. W. - Eilertsen, S. (2010): How did strategic planning help during the economic crisis? Strategy \& Leadership, 38: p. 5-14. http://dx.doi. org/10.1108/10878571011029000 